Background: Em pirical observations have shown that ozonated autohemotherapy markedly improves the symptoms of chronic limb ischemia (muscular pain at rest, in termittent claudication, etc) in ath erosclerotic patien ts, but $m$ echan is $m s$ of action remain unclear.

Aims: Hum an endoth elial cells (HUVECs) are known to release nitrogen monoxide (NO) and we investigated the biological effects of hum anonated serum on HUVECs in culture.

Methods: We assessed the relevance of peroxidation, the release of $\mathrm{NO}$ as nitrite and of three classical cytokin es.

Results: The treatment of HUVECs with ozonated serum yields a dose dependent increase of thiobarbituric acid reactive substances (TBARS) and of hydrogen peroxide $\left(\mathrm{H}_{2} \mathrm{O}_{2}\right)$ and a decrease of protein thiol groups (PTG). Concomitantly, in comparison to eith er the control or the oxygenated sample, there is a significant and steady increase of nitric oxide (NO) production; th is is markedly enhanced by the addition of L-arginine $(20 \mu \mathrm{M})$ and inhibited in the presence of the NO in hibitor, L-NAME $(20 \mathrm{~m} \mathrm{M})$. The main mediator of ozone action is $\mathrm{H}_{2} \mathrm{O}_{2}$ as it has been shown either afte $r$ its direct measurement or by the addition of 20 , 40 and $100 \mu \mathrm{M}$. Moreover, during 24 hours incubation we have investigated the production of endothelin 1 (ET-1), E-selectin and Interleukin 8 (IL-8) and it appears that ozonation enhances IL-8, inhibits E-selectin and hardly modifies ET-1 production.

Conclusions: It appears that reinfusion of ozonated blood, by enhancing release of NO, may induce vasodilation in ischemic areas and reduce hypoxia.

Key words: Ozone, Reactive oxygen species, Hydrogen peroxide, Nitric oxide, Endothelial cells, Endothelin-1, E-selectin, Interleukin-8

\section{Studies on the biological effects of ozone: 11. Release of factors from human endothelial cells}

\author{
Giuseppe Valacchi and Velio Bocci ${ }^{\mathrm{CA}}$
}

Institute of General Physiology, University of Siena, Via A. Moro, 53100 Siena, Italy

\author{
${ }^{\mathrm{CA}}$ Corresponding Author \\ Tel: $(+39) 0577234226$ \\ Fax: (+39) 0577234219 \\ Email: fisgen@unisi.it
}

\section{Introduction}

Blood vessel tone undergoes a complex regulation by vasodilators ( $\mathrm{NO}, \mathrm{CO}$, acetylcoline, adenosine, prostacyclin) and vasoconstrictor factors such as superoxide anion, endothelins, tromboxane, angiotensin II and noradrenaline. ${ }^{1-3}$ In vascular disorders, particularly atherosclerosis, the regulation becomes chaotic owing to the interference of oxidants, adhesion molecules, cytokines and growth factors leading to partial vessel occlusion and hypoxia. Chronic limb ischemia is a progressive disease often observed in atherosclerosis and diabetes leading to necrosis of extremities. Conventional therapy is carried out with infusion of prostanoids, vasodilators and antiaggregants but there is vast empirical evidence ${ }^{4}$ that reinfusion of autologous blood briefly exposed to a gas mixture composed of oxygen-ozone $\left(\mathrm{O}_{2}-\mathrm{O}_{3}\right)$ is similarly, if not more beneficial.

However, so far double-blind randomized clinical trials have not been performed and, for the time being, we considered it worthwhile to investigate whether human ozonated plasma elicits any effects on human umbilical vein endothelial cells (HUVECs) in culture that may help to understand the supposed therapeutic effect. The present data show that reactive oxygen species (ROS) and/or lipid oxidation products (LOP) derived from the interaction of ozone with plasma ${ }^{5}$ enhance the production of nitric oxide (NO), interleukin-8 (IL-8) while the release of either E-selectin or endothelin-1 (ET-1) is either inhibited or hardly modified, respectively.

\section{Materials and methods}

\section{Materials}

Analytical grade $\mathrm{H}_{2} \mathrm{O}_{2} 30 \%$ was purchased from Fluka $\mathrm{GmbH}$, Switzerland. L-Arginine, the NO synthase inhibitor NG-nitro-L-arginine methyl ester (L-NAME) and all the materials not specified below were purchased from Sigma Aldrich srl, Milano, Italy. 


\section{Ozone generation and measurements}

$\mathrm{O}_{3}$ was produced from medical grade $\mathrm{O}_{2}$ using electrical corona arc discharge with a modern $\mathrm{O}_{3}$ generator (Model Ozonosan PM 100K, Hansler GmbH, Iffezheim, Germany) which allows the gas flow rate and $\mathrm{O}_{3}$ concentration to be controlled in real time by photometric determination at $253.7 \mathrm{~nm}$ as recommended by the Standardization Committee of the International Ozone Association. Tygon polymer tubing and glass syringes were used throughout the reaction procedure to ensure containment of $\mathrm{O}_{3}$ and consistency in concentration.

\section{Ozone delivery to biological samples}

A predetermined volume of $\mathrm{O}_{2} / \mathrm{O}_{3}$ gas mixture at various $\mathrm{O}_{3}$ concentrations within the therapeutic range $(20-80 \mu \mathrm{g} / \mathrm{ml}$ of gas perml of serum) was collected with a glass syringe and immediately introduced into a second glass syringe, via a 'Y' connector, containing an identical volume of a pool of human serum (obtained from the Siena Clinical Blood Center). The final gas pressure remained at normal atmospheric pressure. In order to obtain reproducible results it needs to be emphasized that $\mathrm{O}_{3}$ is a very reactive gas so rapid and precise handling is required. Samples were gently but continuously mixed with the gas for $20 \mathrm{~min}$ and afterwards dispensed either into test tubes for analyses or added to cell cultures. Control samples were mixed with an equal volume of $\mathrm{O}_{2}$. It is worth mentioning that $\mathrm{O}_{2}$ represents at least 96\% of the $\mathrm{O}_{2}-\mathrm{O}_{3}$ mixture.

\section{Culture of Human Umbilical Vein Endothelial Cells (HUVECs)}

Primary endothelial cells were obtained from the neonatal umbilical cord vein according to Jaffe et al. ${ }^{6}$ The main vein of umbilical cords (kindly provided by the nursery of 'Le Scotte' hospital of Siena) was thoroughly washed with PBS and then incubated with $10 \mathrm{ml}$ collagenase $(0.2 \%$ dissolved in Medium 199) from Clostridium histiolyticum (type XI, Sigma) for $20-25 \mathrm{~min}$ at $37^{\circ} \mathrm{C}$. The endothelial cells layer was removed from the vein using $50 \mathrm{ml}$ of Hanks buffer (Sigma). The cells were sedimented at $250 \times g$ for $10 \mathrm{~min}$ and washed once with $20 \mathrm{ml}$ of Medium 199 with 20\% FCS (Seromed), and resuspended in $5 \mathrm{ml}$ of fresh medium. Cells were grown in Medium 199, pH 7.4 (Gibco BRL, Rockville, MD) supplemented with $20 \%$ FCS, $2 \mathrm{mM}$ glutamine, $10 \mathrm{mM}$ Hepes, $100 \mu \mathrm{g} / \mathrm{ml}$ heparin, streptomycin-penicillin and $100 \mu \mathrm{g} / \mathrm{ml}$ of endothelial cell growth factor (ECGF). For subculture, the cells were harvested with $0.01 \%$ EDTA- $0.1 \%$ trypsin.

HUVECs were utilized for experiments at 90-95\% $\left(3-3.5 \times 10^{6}\right.$ cell/well) apparent confluence within passage 3 and through 6. Passage were performed according to standardized protocols and by diluting the cell population $1: 3$.

\section{Cell treatment}

The cells were pelleted by centrifugation and seeded in 6 well plates pre-treated with $1.5 \%$ gelatin (type B from bovine skin). To each well $2 \mathrm{ml}$ of M199 supplemented with 1\% FCS, without heparin and ECGF was added for $24 \mathrm{~h}$. The day after cells confluence was around 90-95\% (3-3.5 $\times 10^{6}$ cell/ well). The cells were washed once in Hank's balanced salt solution. Ozonated serum $(2 \mathrm{ml})$ was added to the cells but after $20 \mathrm{~min}$ incubation the serum was collected for biological determination and the cells were grown as described above, but without phenol red in the medium.

\section{Determinations}

Hydrogen peroxide $\left(\mathrm{H}_{2} \mathrm{O}_{2}\right)$ was measured in serum before and after addition of oxygen and ozone by the enzymatic method described by Green and Hill. ${ }^{7}$ Protein thiol groups (PTG) were measured in serum according to $\mathrm{Hu}^{8}$ using procedure 1 with 5,5'-dithiobis(2-nitrobenzoic acid) (DTNB) dissolved in absolute methanol. The thiobarbituric acid (TBA) assay was carried out in serum as described by Buege and Aust. ${ }^{9}$ Values are expressed as $\mu \mathrm{M}$ of TBA reactive substances (TBARS) relative to a malondialdehyde standard. By collecting samples at different incubation times (from 2 to $48 \mathrm{~h}$ ), NO production was assayed by determining the increase in nitrite concentration using the classical Griess reaction. ${ }^{10}$ Cytokines such as IL-8, ET1 and E-selectin present in centrifuged tissue cultured fluids, were kept at $-80^{\circ} \mathrm{C}$ until determinations were carried out by immunoassay using standard kits purchased from R\&D Systems (GmbH, Wiesbaden, Germany). Duplicate samples were diluted 1:1 with the appropriate diluent and a 3-cycle automatic washing process was routinely performed.

\section{Statistical analyses}

All statistical analyses were performed using one-way analysis of variance (ANOVA) with the Scheffé multirange test. All values are expressed as Means and Standard Deviation $( \pm \mathrm{SD})$. $P$ values less than either 0.05 or 0.01 were considered significant and are marked with 1 or 2 asterisks, respectively.

\section{Results}

Initially we investigated whether ozonated human serum added to HUVECs modifies NO production. Figure 1 shows that the exposure of serum for $1 \mathrm{~min}$ to two different concentrations ( 40 and $80 \mu \mathrm{g} / \mathrm{ml}$ of 


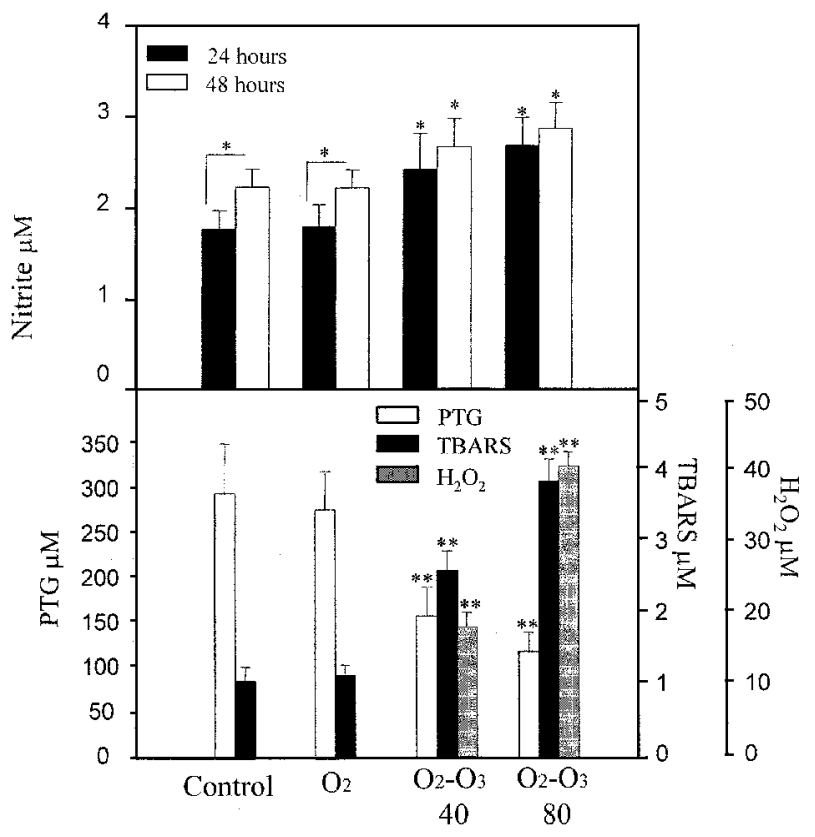

FIG. 1. Effect of different concentrations of ozone on the production of nitrite by HUVECs, 24 and $48 \mathrm{~h}$ after addition of ozonated human serum (top panel). Effect of either oxygen or ozone on PTG, TBARS and $\mathrm{H}_{2} \mathrm{O}_{2}$ levels in the serum before addition to HUVECs. The data are presented as the arithmetic mean $\pm S D$ of 6 different experiments.

gas per $\mathrm{ml}$ of serum) induces a significant $(P<0.01)$ reduction of PTG levels while TBARS and $\mathrm{H}_{2} \mathrm{O}_{2}$ levels increase. Both control serum (untreated) or $\mathrm{O}_{2}$ exposed samples show neither modification of TBARS and PTG values, nor any production of $\mathrm{H}_{2} \mathrm{O}_{2}$. HUVECs incubated with $\mathrm{O}_{2}-\mathrm{O}_{3}$ treated serum samples show an increase of $\mathrm{NO}$ production measured as nitrite, that becomes significant $(P<0.05)$ after 24 and $48 \mathrm{~h}$ and is $\mathrm{O}_{3}$ dose dependent. Nitrite levels were not modified during the first $6 \mathrm{~h}$ of incubation.

Following this we checked if NO release could be influenced by the addition of the substrate L-arginine, or by the inhibitor L-NAME (Fig. 2). L-arginine on its own markedly $(P<0.05)$ increases NO release in both control and $\mathrm{O}_{2}$-serum treated HUVECs but NO production is significantly higher when cultures are added with ozonated serum samples, particularly at ozone concentration of $80 \mu \mathrm{g} / \mathrm{ml}$. The presence of L-NAME inhibits NO release in all cases.

Figure1 shows that ozonation of serum is accompanied by $\mathrm{H}_{2} \mathrm{O}_{2}$ production confirming Pryor's reaction $^{11}$ and our previous data. ${ }^{12}$ Thus it would be interesting to evaluate if $\mathrm{H}_{2} \mathrm{O}_{2}$ is able to influence $\mathrm{NO}$ release. Figure 3 shows that there is an almost linear increase between $\mathrm{NO}$ release and progressively higher amounts (20, 40 and $100 \mu \mathrm{M})$ of $\mathrm{H}_{2} \mathrm{O}_{2}$ added to HUVECs. Moreover addition of L-arginine strongly reinforced NO production while L-NAME inhibited to a great extent, but not entirely, its production.

$\mathrm{H}_{2} \mathrm{O}_{2}$ is now considered a crucial trigger of NF$\mathrm{kB}^{13,14}$ and it appeared obvious to examine whether

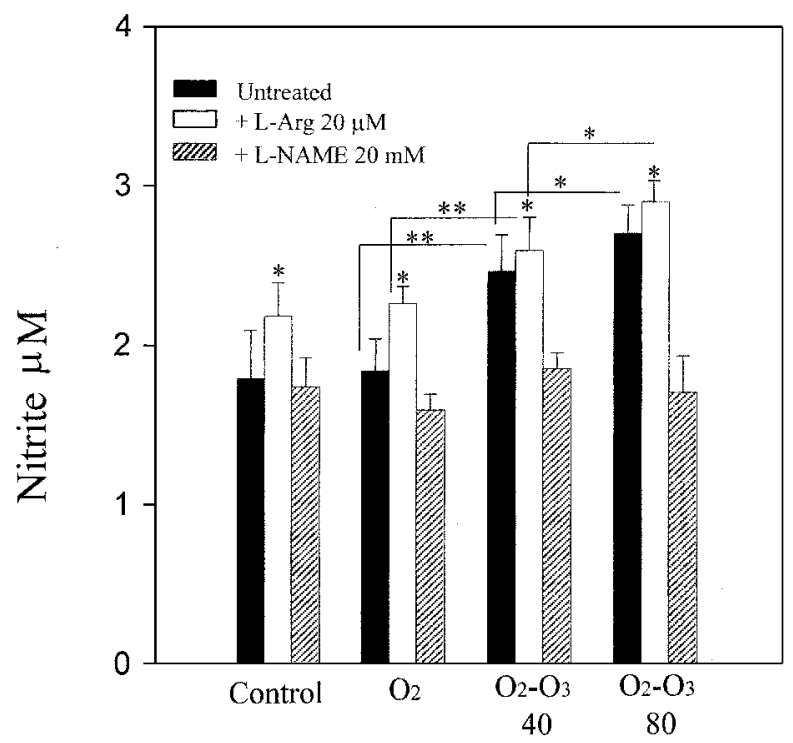

FIG. 2. Production of nitrite by HUVECs, measured after $24 \mathrm{~h}$ incubation, after addition of normal human serum either oxygenated or ozonated (at 40 and $80 \mu \mathrm{g} / \mathrm{ml}$ ). Effects of addition of L-arginine and L-NAME. The data are presented as the arithmetic mean $\pm S D$ of 6 different experiments.

$\mathrm{O}_{3}-\mathrm{H}_{2} \mathrm{O}_{2}$ induces release of a few typical cytokines such as ET-1 (Fig. 4), E-selectin (Fig. 5) and IL-8 (Fig. 6). Ozone at both concentrations ( 40 and $80 \mu \mathrm{g} / \mathrm{ml}$ ) significantly enhances the release of IL-8 after 4, 6 and 24 hours incubation with and without addition of L-arginine confirming the ability of ozone to induce IL-8 production in blood ${ }^{15,16}$ and respiratory epithelial cells. ${ }^{17}$ Release of E-selectin or ET-1 appears either depressed or practically unmodified.

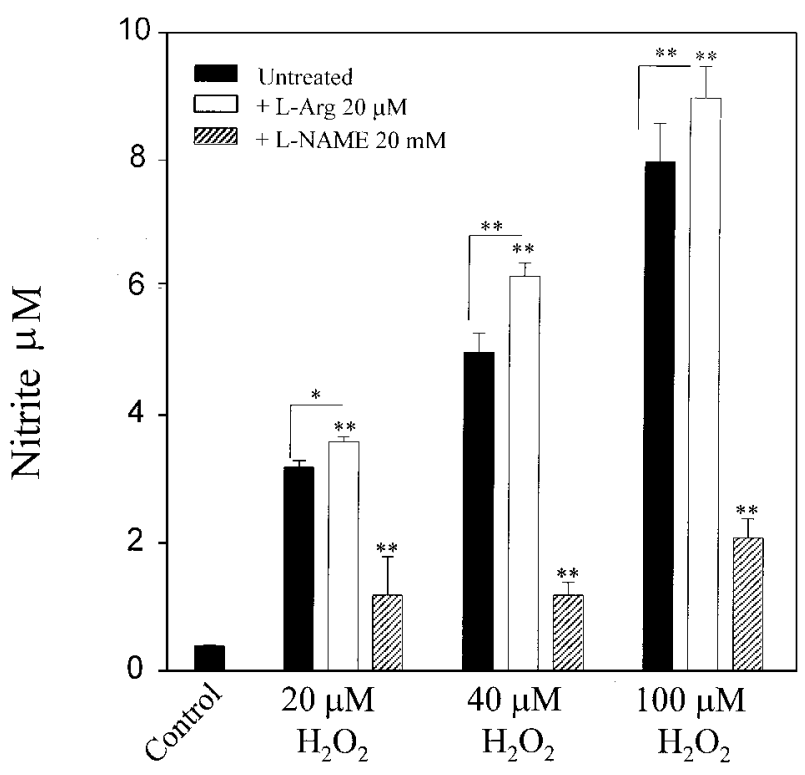

FIG. 3. Production of NO by HUVECs, measured after $24 \mathrm{~h}$ incubation, after addition of three concentration of $\mathrm{H}_{2} \mathrm{O}_{2}$. Effects of the addition of L-arginine and L-NAME. The data are presented as the arithmetic mean \pm SD of 6 different experiments. 


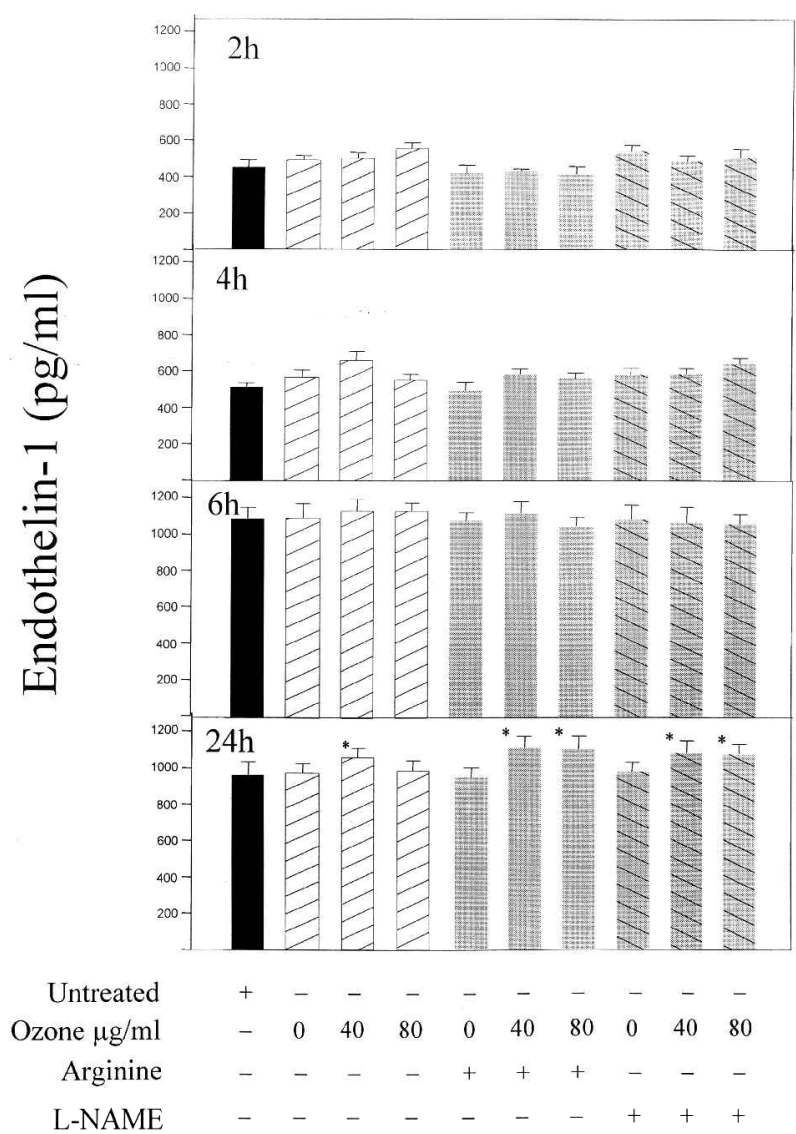

FIG. 4. Kinetic of release of endothelin-1 from HUVECs after addition of human serum either after oxygenation or after ozonation. Effect of the addition of L-arginine and L-NAME. The data are presented as the arithmetic mean \pm SD of 6 different experiments.

\section{Discussion}

Vascular disorders caused by atherosclerosis, diabetes and smoking at the level of the brain, heart and limbs represent a formidable social-economical problem affecting several millions of people worldwide. Orthodox medicine uses a variety of approaches such as surgery, anticoagulants, trombolytic compounds, vasodilators antioxidants and now even gene therapy ${ }^{18}$ for normalizing damaged vessels, reducing restenosis and minimising damage following severe ischemia. During the last decade our laboratory has been involved in clarifying mechanisms of action triggered by ozone when this gas is briefly mixed with human blood. ${ }^{4}$ Like oxygen, ozone dissolves in the plasma and reacts quickly with a number of substrates such as polyunsaturated fatty acids (PUFA), -SH groups present in several compounds and antioxidants. ${ }^{11}$ An array of generated products namely $\mathrm{H}_{2} \mathrm{O}_{2}$, malondialdehyde, 4-hydroxynonenal, hydroperoxides and lipoperoxides ${ }^{19}$ may act as cellular signals and trigger biological effects. It must be said that these compounds, depending on their concentrations, seem to behave as a double-edged sword. ${ }^{20}$ For this reason we have been very careful in defining the biological active dose that, in terms of ozone concentration, ranges between 20 and $80 \mu \mathrm{g} / \mathrm{ml}$ gas perml of blood without displaying toxic effects neither in vitro nor in vivo ${ }^{4,21}$ Empirical observations have shown that ozone enhances delivery of oxygen to hypoxic tissue and we have hypothesized that ozonated plasma during reinfusion may elicit some effects on the vessel wall possibly enhancing vasodilatation. Indeed the present results give credence to this idea by showing an enhanced production of $\mathrm{NO}$, which is an important component of the negative feed-back loop that prevents thrombogenesis. The adherence of platelets to the vessel wall, and their aggregation, is suppressed by nitrovasodilators capable of increasing the intracellular cGMP, with consequent phosphorylation of cGMP-dependent phosphoproteins and suppression of platelet reactivity. ${ }^{22}$ The possible formation in vivo of nitrosocompounds, with longer lifetime than NO, may slowly decrease the vasospasm.

Our data showing inhibition of release of E-selectin, especially after 2 and 6 hours, and no increase of ET-1. This is consistent with previous reports ${ }^{23-26}$ showing a reciprocal regulation of the expression of ET-1 and endothelial cell adhesion molecules in comparison to

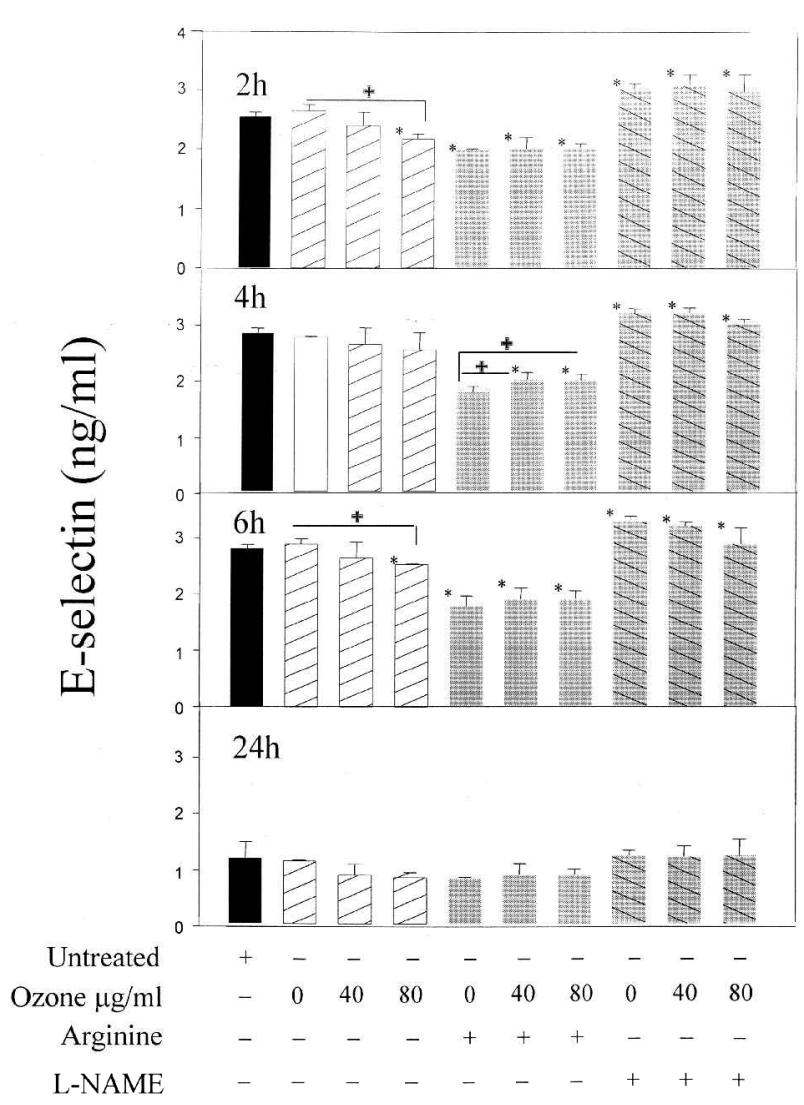

FIG. 5. Kinetics of release of E-selectin from HUVECs after addition of human serum either after oxygenation or after ozonation. Effect of the addition of L-arginine and L-NAME. The data are presented as the arithmetic mean \pm SD of 6 different experiments. 


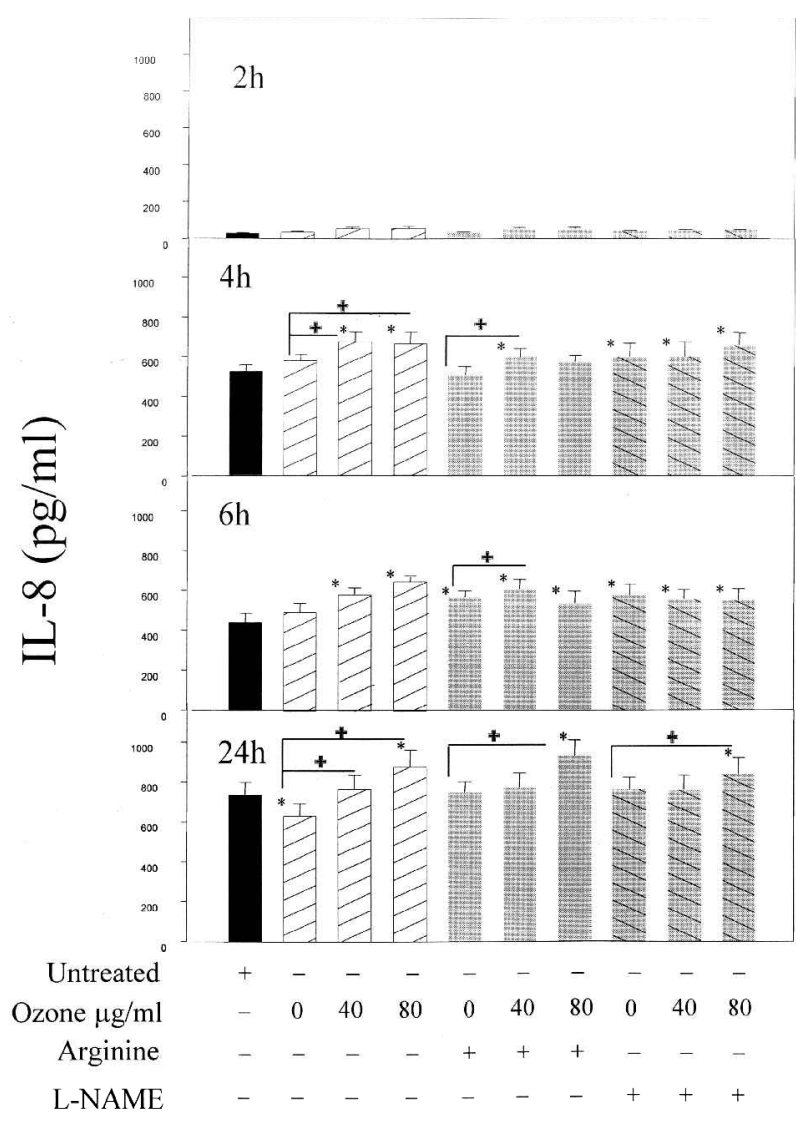

FIG. 6. Kinetics of release of IL-8 from HUVECs after addition of human serum either after oxygenation or after ozonation. Effect of the addition of L-arginine and L-NAME. The data are presented as the arithmetic mean \pm SD of 6 different experiments.

production of NO. At present, we cannot say whether ozonated serum is able to increase gene expression of $\mathrm{VEGF}^{27}$ that is whether a potent mitogen that by stimulating neoangiogenesis may be helpful in coronary and critical leg ischemia. This is a very important point that unfortunately has not been clarified. However Chua et al. ${ }^{28}$ have clearly shown that VEGF mRNA was expressed in a dose- and time-dependent manner when rat heart endothelial cells were exposed to $0.5-1 \mathrm{mM} \mathrm{H}_{2} \mathrm{O}_{2}$.

In conclusion we have shown for the first time that human serum briefly exposed to biologically active and atoxic ozone concentration (from 20 to $80 \mu \mathrm{g} / \mathrm{ml}$ per $\mathrm{ml}$ of plasma) after a 20 min incubation with HUVECs induces $\mathrm{H}_{2} \mathrm{O}_{2}$ production (up to $40 \mu \mathrm{M})$. This concentration is possibly underestimated because it has been observed ${ }^{12}$ that the mean half-life of $\mathrm{H}_{2} \mathrm{O}_{2}$ in plasma is about $2 \mathrm{~min}$. Addition of $\mathrm{H}_{2} \mathrm{O}_{2}$ to HUVECs, in turn, as we have now shown, induces a dose-dependent increase of NO further enhanced by L-arginine. It must be emphasized that HUVECs were kept in contact with ozonated serum for only $20 \mathrm{~min}$. This approximately corresponds to the period of time of blood reinfusion. So far we have not addressed the issue of whether NO production is due to constitutively present NOsynthase $\left(\mathrm{Ca}^{++}\right.$dependent), typical of the endothelium, or the newly induced enzyme (iNOS, $\mathrm{Ca}^{++}$ independent) which seems most likely as at 2, 4 and 6 hours after treatment we could not measure any nitrite increase. However work in progress will clarify this question and elucidate whether ozonated plasma added to HUVECs, simulating the reinfusion of ozonated blood in patients, is able to induce neoangiogenesis.

ACKNOWLEDGEMENTS. This work has been supported by Murst grant. The careful revision and preparation of the manuscript by Mrs Helen Carter and Mrs Patrizia Marrocchesi is gratefully acknowledged.

\section{References}

1. Levin ER. Endothelins. N Engl J Med 1995; 333: 356-363.

2. Katusic ZS. Superoxide anion and endothelial regulation of arterial tone. Free Radical Biol Med 1996; 20: 443-448.

3. Cines DB, Pollak ES, Buck CA, Loscalzo J, Zimmerman GA, McEver RP, Pober JS, Wick TM, Konkle BA, Schwartz BS, Barnathan ES, McCrae KR, Hug BA, Schmidt AM, Stern DM. Endothelial cells in physiology and in the pathophysiology of vascular disorders. Blood 1998; 91: 3527-3561

4. Bocci V. Biological and clinical effects of ozone. Has ozonetherapy any future in medicine? Brit J Biomed Sci 1999; 56: 270-279.

5. Pryor WA, Squadrito GL, Friedman M. The cascade mechanism to explain ozone toxicity: the role of lipid ozonation products. Free Radical Biol Med 1995; 19: 935-941.

6. Jaffe EA, Nachman RL, Becker CG, Minick CR. Culture of human endothelial cells derived from umbilical veins. Identification by morphologic and immunologic criteria. J Clin Invest 1973; 52: 2745-2756.

7. Green MJ, Hill HAO. Chemistry of dioxygen. Meth Enzymol 1984; 105: 3-22.

8. Hu M-L. Measurement of protein thiol groups and glutathione in plasma. Meth Enzymol 1994; 233: 380-385.

9. Buege JA, Aust SD. Microsomal lipid peroxidation. Meth Enzym ol 1994; 233: 302-310.

10. Moshage H, Kok B, Huizenga JR, Jansen PL. Nitrite and nitrate determinations in plasma: a critical evaluation. Clin Chem 1995; 41: 892-896.

11. Pryor WA. Mechanisms of radical formation from reactions of ozone with target molecules in the lung. Free Radical Biol Med 1994; 17: 451-465.

12. Bocci V, Valacchi G, Corradeschi F, Aldinucci C, Silvestri S, Paccagnini E, Gerli R. Studies on the biological effects of ozone: 7. Generation of reactive oxygen species (ROS) after exposure of human blood to ozone. $J$ Biol Regulat Ho meost Agent 1998; 12: 67-75.

13. Baeuerle PA, Henkel T. Function and activation of NF-kB in the immune system. Annu Rev Im munol 1994; 12: 141-179.

14. Ginn-Pease ME, Whisler RL. Redox signals and NF-kB activation in T cells. Free Rad Biol Med 1998; 25: 346-361.

15. DeForge LE, Fantone JC, Kenney JS, Remick DG. Oxygen radical scavengers selectively inhibit interleukin 8 production in human whole blood. J Clin Invest 1992; 90: 2123-2129.

16. Bocci V, Valacchi G, Corradeschi F, Fanetti G. Studies on the biological effects of ozone: 8. Effects on the total antioxidant status and on interleukin-8 production. Mediat Infla $m m$ 1998; 7: 313-317.

17. Jaspers I, Flescher E, Chen LC. Ozone-induced IL-8 expression and transcription factor binding in respiratory epithelial cells. Amer J Physio 1997; 272: L504-L511.

18. Laitinen M, Mäkinen K, Manninen H, Matsi P, Kossila M, Agrawal RS, Pakkanen T, Luoma JS, Viita H, Hartikainen J, Alhava E, Laakso M, YläHerttuala S. Adenovirus-mediated gene transfer to lower limb artery of patients with chronic critical leg ischemia. Hum Gene Ther 1998; 9: 1481-1486.

19. Pryor WA. Ozone in all its reactive splendor. J Lab Clin Med 1993; 122 : 483-486.

20. Dianzani MU. 4-Hydroxynonenal and cell signalling. Free Rad Res 1998; 28: 553-560.

21. Di Paolo N, Bocci V, Garosi G, Borrelli E, Bravi A, Bruci A, Aldinucci C, Capotondo L. Extracorporeal blood oxigenation and ozonation (EBOO) in man. Preliminary report. Int J Artif Organs 2000; 23: 131-141.

22. Cooke JP, Dzau VJ. Derangements of the nitric oxide synthase pathway, L-arginine, and cardiovascular diseases. Circulation 1997; 96: 379-382.

23. Flowers MA, Wang Y, Stewart RJ, Patel B, Marsden PA. Reciprocal regulation of endothelin-1 and endothelial constitutive NOS in proliferating endothelial cells. Am J Physiol 1995; 269: H1988-H1997. 
24. Takahashi M, Ikeda U, Masuyama J, Funayama H, Kano S, Shimada K Nitric oxide attenuates adhesion molecule expression in human endothelial cells. Cytokine 1996; 8: 817-821.

25. Armstead VE, Minchenko AG, Schuhl RA, Hayward R, Nossuli TO, Lefer AM. Regulation of P-selectin expression in human endothelial cells by nitric oxide. Am J Physiol 1997; 273: H740-H746.

26. Cartwright JE, Whitley GS, Johnstone AP. Endothelial cell adhesion molecule expression and lymphocyte adhesion to endothelial cells: effect of nitric oxide. Exp Cell Res 1997; 235: 431-434.
27. Ferrara N, Davis-Smyth T. The biology of vascular endothelial growth factor. Endo cr Rev 1997; 18: 4-25.

28. Chua CC, Hamdy RC, Chua BHL. Upregulation of vascular endothelial growth factor by $\mathrm{H}_{2} \mathrm{O}_{2}$ in rat heart endothelial cells. Free Rad Biol Med 1998; 25: 891-897.

Received 1 September 2000;

accepted after revision 20 October 2000 


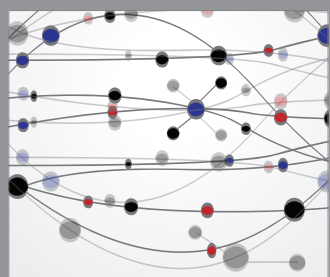

The Scientific World Journal
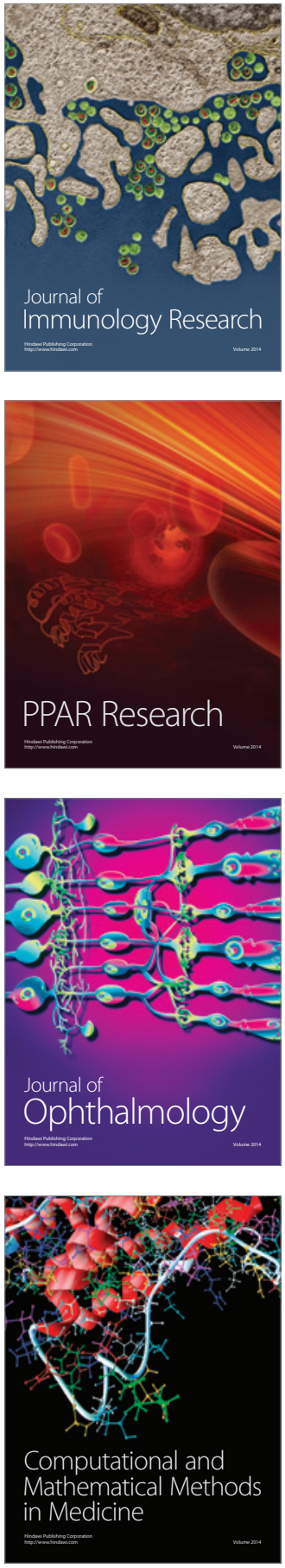

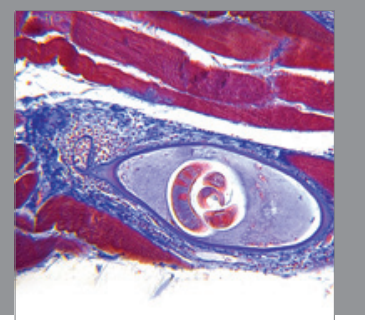

Gastroenterology

Research and Practice
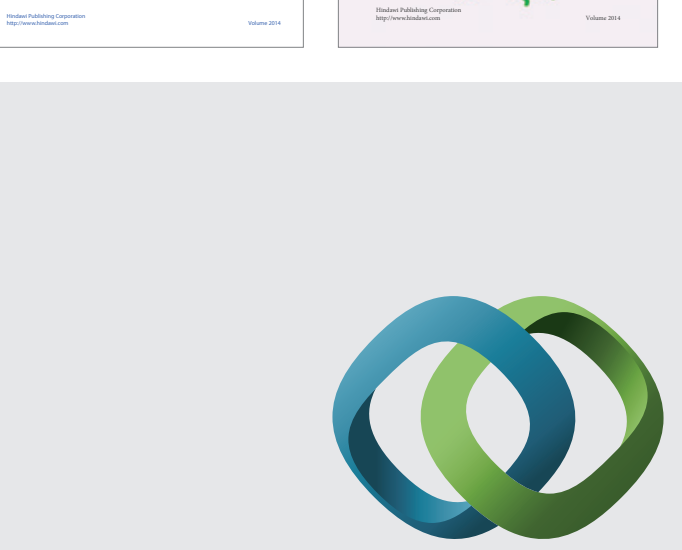

\section{Hindawi}

Submit your manuscripts at

http://www.hindawi.com
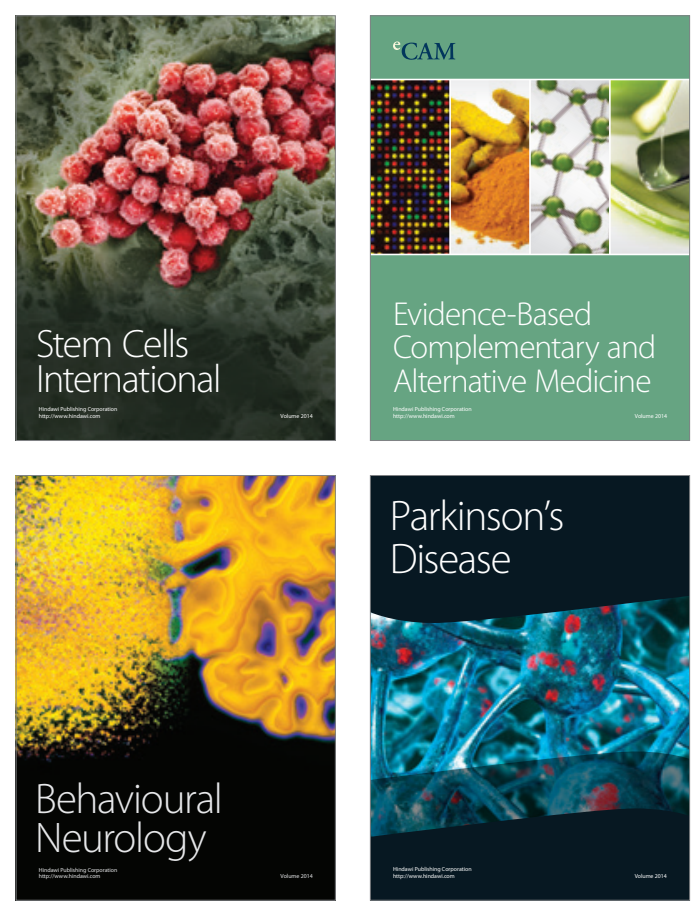

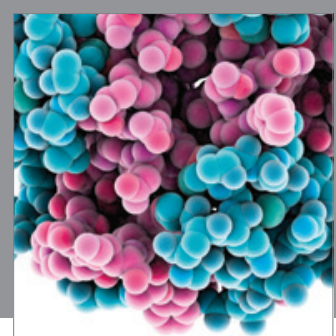

Journal of
Diabetes Research

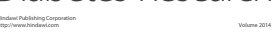

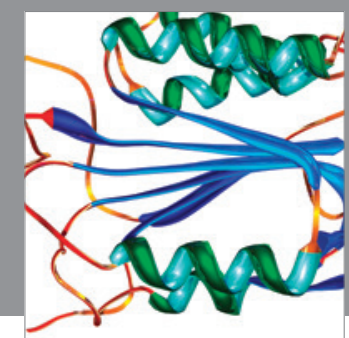

Disease Markers
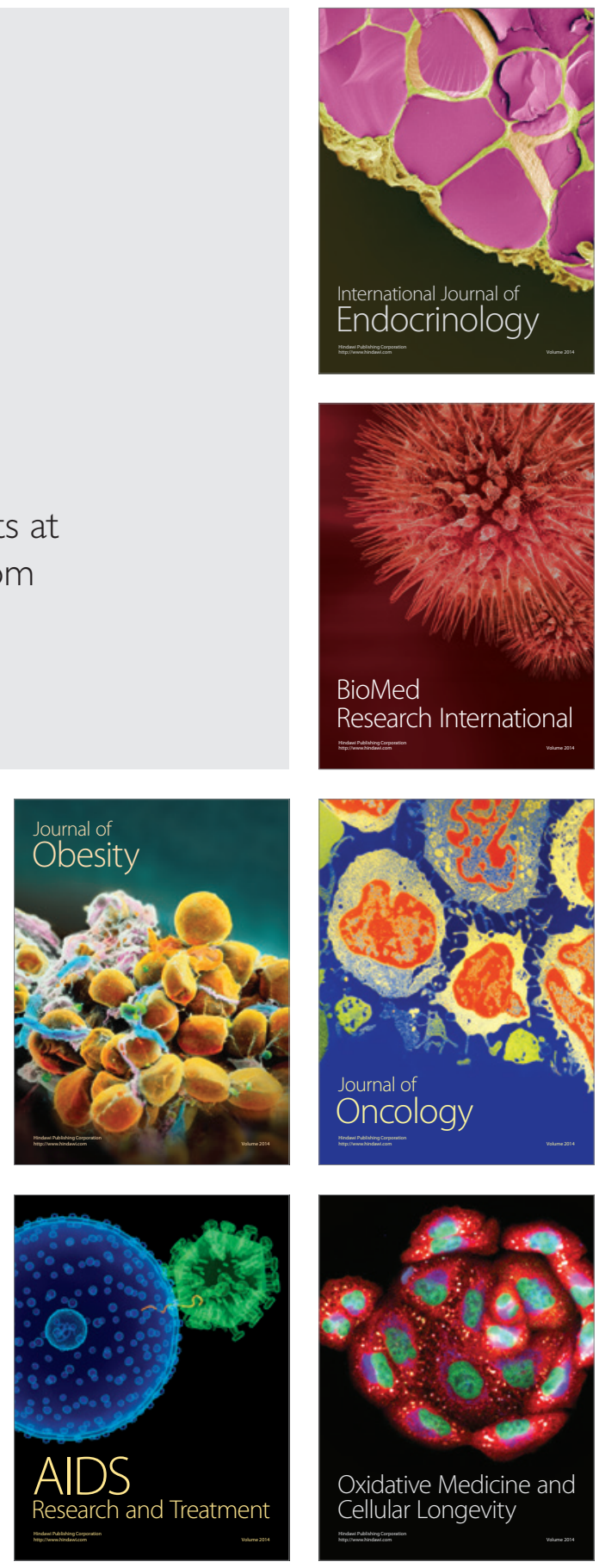